\title{
Postharvest quality of fresh murici fruits as a function of storage and packing ${ }^{1}$
}

\author{
Nayane Rosa Gomes ${ }^{2}$, Bianca Soares Pierre ${ }^{2}$, \\ Cristiane Maria Ascari Morgado², André José de Campos²
}

\section{ABSTRACT}

Murici is a typical Brazilian Savanna fruit widely consumed by local communities. This study aimed to evaluate the postharvest quality of murici fruits as a function of storage and packing. The experiment followed a triple factorial scheme ( $3 \times 2 \times 9)$, evaluating three packing materials (polypropylene, low-density polyethylene and nylon/polyethylene), two atmosphere conditions (vacuum and non-vacuum) and 9 days of analysis $(0,2,4,6,8,10,12,14$ and 16 days). The fruits were evaluated for fresh weight loss, firmness, total chlorophyll, total extractable polyphenols and total antioxidant activity. As for refrigeration, the vacuum treatments showed a lower fresh weight loss for fruits packed with nylon or polypropylene. Firmness decreased along the experiment, regardless of packing and atmosphere condition. The antioxidant activity increased up to the end of storage in all the treatments. Both the polypropylene and nylon/polyethylene under vacuum packing showed the best results for maintaining the murici quality.

KEYWORDS: Brysonima spp., flexible packing, bioactive compounds.

\section{INTRODUCTION}

Brazilian Savanna plants, mainly the fruit ones, are known for their sensory properties and high nutritional quality, with compounds of great biotechnological interest to the medical and food industries (Caramori et al. 2004, Morzelle et al. 2015). One of the typical Brazilian Savanna plants is muricizeiro (Byrsonima spp.), which is found throughout Latin America and comprises about 130 species.

In Brazil, murici fruits are consumed mainly fresh and ripen from December to March, in mountainous regions of the Southeast, Brazilian

\section{RESUMO}

Qualidade pós-colheita de frutos frescos de murici em função do armazenamento e embalagem

Murici é um fruto típico do Cerrado amplamente consumido por comunidades locais. Objetivou-se avaliar a qualidade póscolheita de frutos de murici em função do armazenamento e embalagem. $\mathrm{O}$ experimento seguiu esquema fatorial triplo ( $3 \times 2 \times 9)$, avaliando-se três tipos de embalagem (polipropileno, polietileno de baixa densidade e naylon/polietileno), duas condições de atmosfera (vácuo e sem vácuo) e 9 dias de análise $(0,2$, 4, 6, 8, 10 , 12,14 e 16 dias). Os frutos foram avaliados quanto à perda de massa fresca, firmeza, clorofila total, polifenóis extraíveis totais e atividade antioxidante total. Quanto à refrigeração, os tratamentos a vácuo apresentaram menor perda de massa fresca nos frutos embalados com naylon ou polipropileno. A firmeza diminuiu com o decorrer do experimento, independentemente da embalagem e da condição de atmosfera. A atividade antioxidante aumentou até o final do armazenamento em todos os tratamentos. Tanto o polipropileno quanto o naylon/polietileno embalados a vácuo apresentaram os melhores resultados para a manutenção da qualidade do murici.

PALAVRAS-CHAVE: Brysonima spp., embalagens flexíveis, compostos bioativos.

Savanna areas in the states of Mato Grosso and Goiás, and on the coastal areas of North and Northeast. When ripe, the fruit is yellowish, 1.5 to $2.0 \mathrm{~cm}$ in diameter, and has a strong odor like rancid cheese (Belisário \& Coneglian 2013) and limited postharvest shelf life (Mota 2014). Therefore, postharvest technologies are needed to extend its trading period (Cerqueira 2007).

Refrigeration is the main technology to maintain fruit quality, but it is often insufficient or cause physiological disorders. Therefore, other techniques can be used to complement or improve the existing conservation system, such as chemical treatments and modified atmosphere packing (Lima et al. 2015). In this regard, the latter is a storage

\footnotetext{
${ }^{1}$ Received: Dec. 22, 2020. Accepted: Feb. 26, 2021. Published: May 25, 2021. DOI: 10.1590/1983-40632021v5167185.

${ }^{2}$ Universidade Estadual de Goiás, Anápolis, GO, Brasil. Email/ORCID: nayanerosa@hotmail.com/0000-0001-5290-4966, biancasoarespierre@gmail.com/0000-0001-5203-7487, cristianemorgado4@yahoo.com.br/0000-0002-6319-344X, andre.jose@ueg.br/0000-0002-5958-8107.
} 
technique wherein fruits and vegetables are subjected to atmosphere conditions other than the normal ones, changing mainly concentrations of gases (Machado et al. 2007).

Changes in the atmosphere conditions serve as a suitable barrier to water vapor, oxygen and ultraviolet radiation, slowing down ripening and water loss, thus decreasing food spoilage (Mueller et al. 2012). They can be induced by using materials such as polyethylene, polypropylene, polyethylene terephthalate, and even multilayer systems. These are composed of two or more layers of the same material or different materials, which can improve barriers to a system, when compared to each material in isolation (Fabris et al. 2006). For example, two-layer composites of nylon and polyethylene promote a gas barrier, increasing material resistance and decreasing product darkening, which are desirable in vacuum packing (Vieites et al. 2014).

There are two types of modified atmosphere used in packing: active and passive. The first consists of air removal (vacuum) (Prentice \& Sainz 2005) and/or injection of a known gas composition, while packing a product. The latter is provided by fruit respiration, where gas concentrations are uncontrolled, varying with time, temperature, polymer permeability and fruit respiratory activity (Arruda et al. 2011). Both types of modified atmosphere storages consist of technological food preservation processes (Prentice \& Sainz 2005) that can help to reduce the metabolic activity of products by limiting the main mechanisms of food deterioration, such as gas exchange with external medium, enzymatic action and oxidation, thus preserving products for longer periods (Alegretti et al. 2015).

Given this background, searching for efficient techniques to preserve quality and prolong the postharvest life of murici fruits becomes relevant, given their perishability and nutritional value. Therefore, this study aimed to assess the postharvest quality of murici fruits submitted to packing systems and storage conditions.

\section{MATERIAL AND METHODS}

Murici fruits were harvested at the Córrego do Meio farm, in Diorama, Goiás state, Brazil (16 $6^{\circ} 14^{\prime} 02^{\prime}$ 'S, 51 ${ }^{\circ} 15^{\prime} 21^{\prime \prime} \mathrm{W}$ and $506 \mathrm{~m}$ of altitude), in January 2018. The fruits were manually collected after reaching the maturity stage for commercial consumption, namely when the peel turns yellowishgreen. There is a reserve area of Brazilian Savanna in the studied farm with more than 40 murici plants of the same species. Thus, the fruits were gathered from several plants full of fruits, which were close to each other.

After harvesting, the fruits were transported in high-density polyethylene trays to the laboratory, where they were manually and visually selected for the absence of rot and injuries and then subjected to treatments.

Before the treatment, the fruits were sanitized in a $2 \%$ sodium hypochlorite solution for $10 \mathrm{~min}$ and then rinsed in distilled water to remove the sanitizer and its possible effects. First, the fruits were packed using three polymer materials: polypropylene, lowdensity polyethylene and nylon/polyethylene. Second, they were subjected to two changes in the atmosphere conditions: vacuum and non-vacuum. Finally, the treatments were assessed for nine days after the treatment $(0,2,4,6,8,10,12,14$ and 16 days).

The treatments were kept in biochemical oxygen demand incubators at $12 \pm 2{ }^{\circ} \mathrm{C}$ and $60 \pm 4 \%$ of relative humidity ( $\mathrm{RH}$; measured by a thermohygrometer during the entire experiment), for 16 days. Then, they were evaluated every two days for fresh weight loss, pulp firmness, total chlorophyll contents, total extractable polyphenols and total antioxidant activity.

The fresh weight loss was always evaluated using the same fruits, which were weighed on a Mark 500 analytical scale (Tepron, São Paulo, Brazil) with $0.001 \mathrm{~g}$ accuracy and $500 \mathrm{~g}$ maximum load. This parameter was calculated as the difference between the initial fruit weight and that at each interval of storage time. The results were expressed as percentage.

The firmness was assessed by a texture meter (Texture analyzer CT3 50K, Massachusetts, USA), at a penetration speed of $6.9 \mathrm{~mm} \mathrm{~s}^{-1}$ and longitudinal section, using a cylindrical test tip (TA44) with $4 \mathrm{~mm}$ in diameter and penetration depth of $1.8 \mathrm{~mm}$, in duplicate per fruit. The results were expressed as Newton.

The chlorophyll content was determined using the method by McKinney (1941) and Lichtenthaler (1987), with adaptations, using a fraction of about $50 \mathrm{mg}$ of fresh fruit per replication. The results were expressed as $\mathrm{mg} \mathrm{g}^{-1}$ of pulp. 
The total extractable polyphenols from the extracts were determined in a spectrophotometer, using a phenol reagent (Folin Ciocalteau), according to Obanda \& Owuor (1997), adapted by Rufino et al. (2010). The results were expressed as mg of gallic acid equivalent per $100 \mathrm{~g}$ of pulp.

The antioxidant activity was assessed by capturing the free radical 2,2-diphenyl-1picrylhydrazyl (DPPH), following the BrandWilliams et al. (1995) method adapted by Rufino et al. (2010), in which the results are expressed as $\mathrm{EC}_{50} \mathrm{~g} \mathrm{~g}^{-1}$ of DPPH.

To check the combined effect of packing materials and atmosphere conditions on the postharvest conservation of fresh murici fruits, a fully randomized design was used, with a $3 \times 2 \times 9$ triple factorial scheme (packing material $\mathrm{x}$ atmosphere conditions $\mathrm{x}$ day of analysis) and 4 replications, with 7 fruits each.

The data were subjected to analysis of variance $(p<0.05)$. When significant, the means were compared by the Tukey test at $5 \%$ of probability (qualitative data) and regression analysis (quantitative data). All statistical analyses were performed using the Sisvar 5.6 software (Ferreira 2011).

\section{RESULTS AND DISCUSSION}

The vacuum treatments showed less fresh weight loss in fruits packed with nylon (nylon/ polyethylene) or polypropylene (Table 1). This might be because vacuum reduces the oxygen levels in fruits during storage. By contrast, fruits packed with low-density polyethylene showed no statistical differences, whether under vacuum or not.

The low-density polyethylene packing is tough at room and low temperatures (with sufficient mechanical strength for many applications), corrosionresistant, highly insulating, odorless, tasteless and highly permeable to water vapor. These properties are

Table 1. Fresh weight loss (\%) of fresh murici fruits stored under different packing and atmosphere conditions and refrigerated $\left(12 \pm 2{ }^{\circ} \mathrm{C}\right.$ and $60 \pm 4 \%$ of $\left.\mathrm{RH}\right)$ for 16 days.

\begin{tabular}{lccc}
\hline \multirow{2}{*}{ Atmosphere } & \multicolumn{4}{c}{ Packing } \\
\cline { 2 - 4 } & PP & LDPE & NY/PE \\
\hline Non-vacuum & $0.0269 \mathrm{cA}^{*}$ & $0.0419 \mathrm{aA}$ & $0.0325 \mathrm{bA}$ \\
Vacuum & $0.0263 \mathrm{bA}$ & $0.0402 \mathrm{aA}$ & $0.0252 \mathrm{bB}$ \\
\hline * Means followed by the same letter, lowercase in the row and uppercase in the \\
column, do not differ statistically from each other by the Tukey test at $5 \%$ of \\
significance. PP: polypropylene; LDPE: low-density polyethylene; NY/PE: \\
nylon/polyethylene.
\end{tabular}

of great importance from industrial and technological points of view. Yet, when compared to nylon/ polyethylene packing, low-density polyethylene is more permeable to gas and water vapor (Crippa et al. 2007). This may explain the absence of significant differences for mass loss among fruits packed with such film. As for the polypropylene with or without vacuum, there was no difference in mass loss.

Based on that, both nylon/polyethylene and polypropylene can be used along with vacuum atmosphere, since fresh murici fruits had less weight losses in these systems. During the evaluation, polypropylene and nylon/polyethylene had no relevant changes (Figure 1), showing to be efficient in maintaining the fruit weight. This probably occurred due to declines in fruit respiratory rates, forming a barrier against water and gas losses $\left(\mathrm{O}_{2}\right.$ and $\left.\mathrm{CO}_{2}\right)$.

On the other hand, the low-density polyethylene packing showed an increase in respiratory rates and greater fruit weight losses during storage. Likewise, when evaluating 'Douradão' peaches packed in polypropylene and low-density polyethylene films, Santana et al. (2011) observed that low-density polyethylene was inefficient in reducing fruit mass losses during storage.

Fruit fresh weight loss during storage is a limiting factor for both marketability and conservation. Although the pulp is often in good condition for consumption, the fruit peel develops a shriveled and wilted appearance (Brunini \& Cardoso 2011). However, this was not observed in this study, where the three tested packing materials provided a minimal weight loss. Among them, the low-density polyethylene packing showed losses slightly higher than the others, maybe due to its greater water vapor permeation (Crippa et al. 2007).

It is worth noting that the fresh weight loss was minimal in refrigerated fruits, regardless of packing or atmosphere conditions. Thus, packing and refrigerated atmosphere, with and without vacuum, kept the fruit weight.

In short, all packing materials could protect fruits against any deteriorating action, whether chemical, physical or microbiological, from packing until their final consumption (Souza et al. 2012). Therefore, fruits had their characteristics preserved for a longer time (16 days).

Pulp firmness is another important quality property of fruits. Its maintenance is one of the goals in postharvest conservation techniques (Nassur et al. 


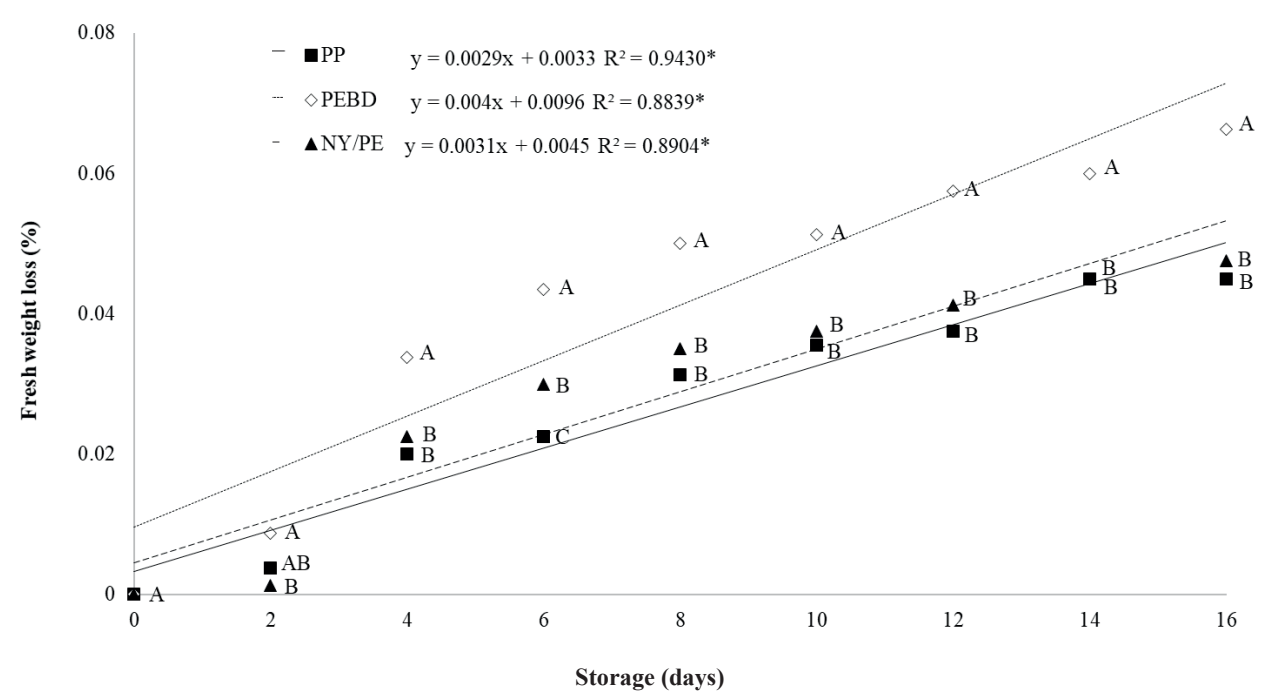

Figure 1. Fresh weight loss of fresh murici fruits packed in different materials and stored at $12 \pm 2{ }^{\circ} \mathrm{C}$ and $60 \pm 4 \%$ of $\mathrm{RH}$, for 16 days. * Significant at $5 \%$ of probability. Means followed by the same letter in the column do not differ statistically from each other by the Tukey test at $5 \%$ of significance. PP: polypropylene; LDPE: low-density polyethylene; NY/PE: nylon/ polyethylene.

2016), once firmer fruits are less subject to mechanical injuries during transport and trading (Tomaz et al. 2009). In this study, firmness decreased with the course of the experiment, regardless of packing and analyzed atmosphere condition (Figures 2 and 3). The reduction was quadratic and similar among all the treatments (Figure 2), but firmer fruit pulps were observed in polypropylene packing at the end of storage. This polymer film maintained firmness for a longer time, if compared to the other materials, with significant differences after day 12. Allied to the low weight loss (Figure 1) provided by the polypropylene packing, such maintenance of pulp firmness was beneficial, as it prevented the hardening of epicarp cells, making fruits more suitable for marketing.

Regardless of packing or atmosphere condition, the pulp firmness values were higher in refrigerated fruits, therefore, demonstrating the cooling effect on plant metabolism. These findings were within the range of firmness found by Lourenço et al. (2013) (between 1.83 and $9.07 \mathrm{~N}$ ), who evaluated 18 genotypes of murici (Byrsonima dealbata) harvested in the cities of Pacajus, Fortaleza and Paraíba (Ceará State, Brazil).

Sampaio (2015) evaluated B. ligustrifolia fruits at five ripening stages (green, light pink, red, purple-red and black-purple epicarp) and found that green fruits are firmer. In other words, the riper the fruit, the less firm it is. Moreover, fruits soften due to the enzymatic activity that hydrolyzes pectin (cell wall compound) or starch. This was also observed in this study, as the storage days progressed.

Regardless of vacuum application, the fruit firmness decreased during storage (Figure 3), but the vacuum atmosphere condition maintained the pulp firmness, with higher and significant averages from the 6th day onwards. Silva et al. (2014) compared passive and active atmosphere conditions and found that the absence of vacuum provided less firmness $(2.43 \mathrm{~N})$ to Myrciaria cauliflora fruits, when compared to vacuum-packed ones (3.22 N). This outcome corroborates that of Dias et al. (2011), who also claimed that vacuum storage is more effective for controlling fruit firmness.

As for total chlorophyll content, it was observed no significant difference for low-density polyethylene packing with or without vacuum, which differed from the other packing systems. By contrast, the vacuum nylon/polyethylene packing presented higher chlorophyll contents, followed by vacuum polypropylene and low-density polyethylene packing (Table 2).

Crippa et al. (2007) stated that, in general, nylon packing promotes an effective barrier to oxygen, besides a high resistance to mechanical (abrasion, perforation, impact, flexion) and thermal stresses, as well as to oils, fats and chemicals. Such features may explain the present results of 


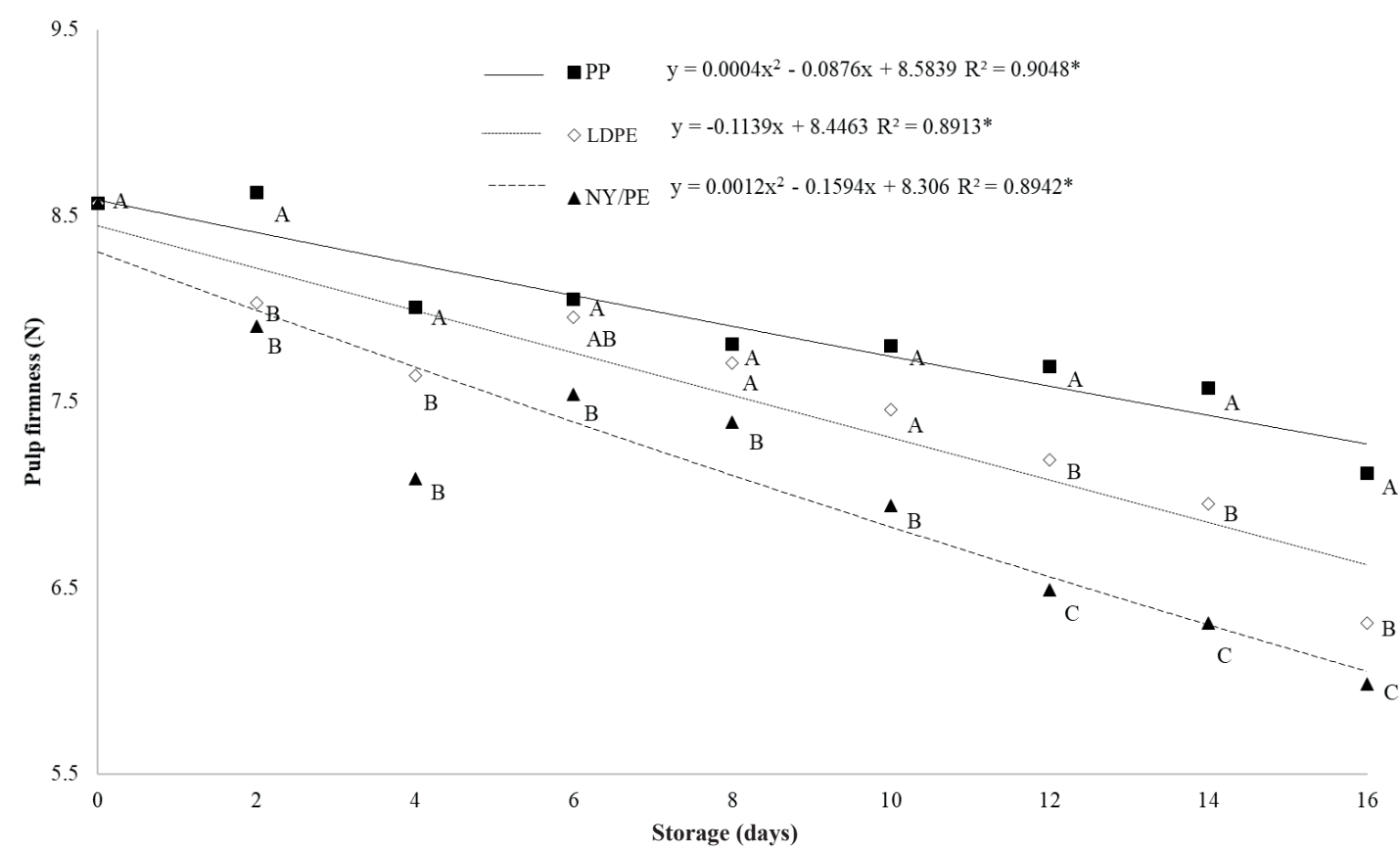

Figure 2. Pulp firmness of fresh murici fruits packed in different materials and stored at $12 \pm 2{ }^{\circ} \mathrm{C}$ and $60 \pm 4 \%$ of $\mathrm{RH}$, for 16 days. * Significant at $5 \%$ of probability. Means followed by the same letter in the column do not differ statistically from each other by the Tukey test at $5 \%$ of significance. PP: polypropylene; LDPE: low-density polyethylene; NY/PE: nylon/polyethylene.

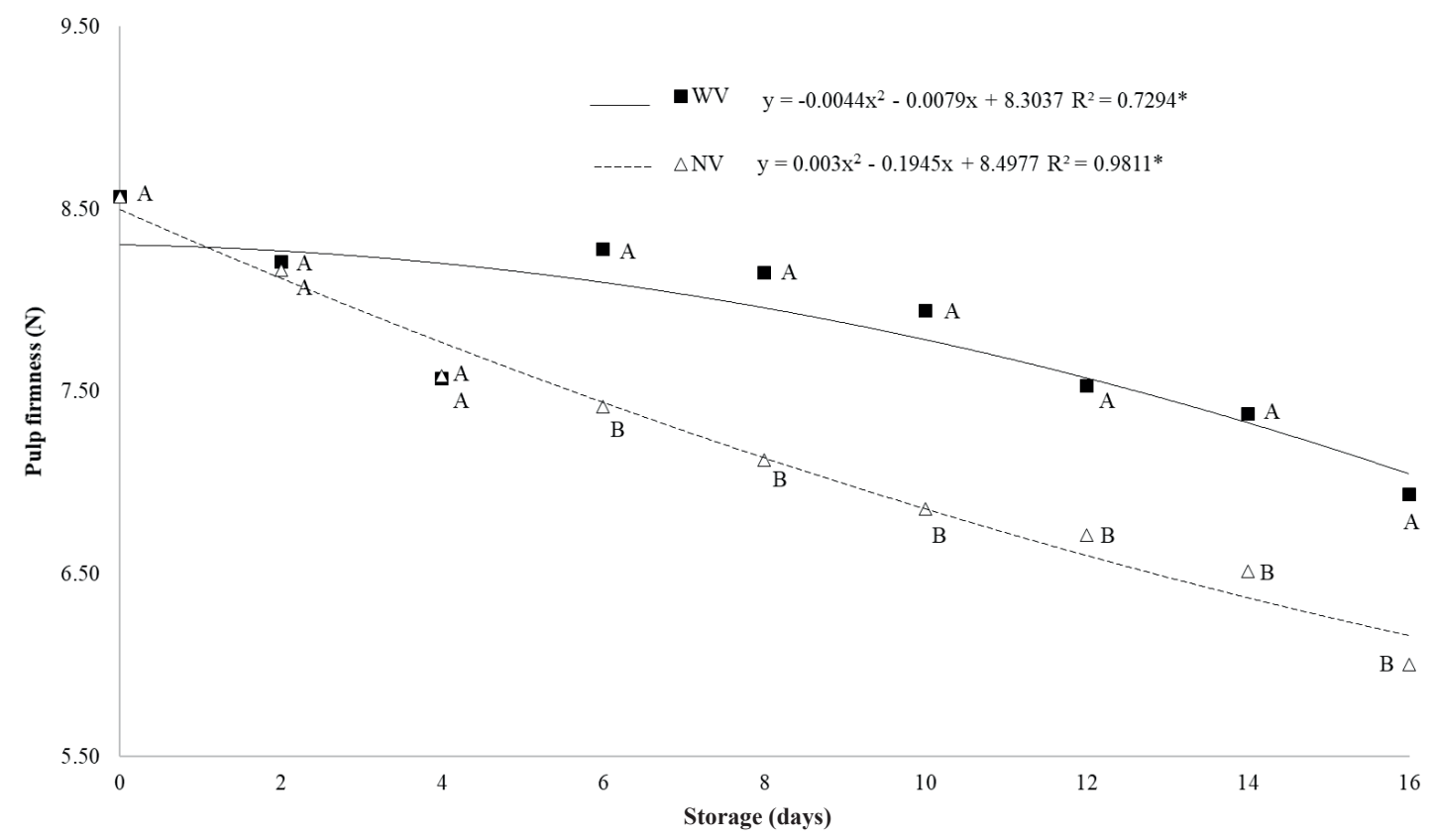

Figure 3. Pulp firmness of fresh murici fruits packed in different modified atmospheres and stored at $12 \pm 2{ }^{\circ} \mathrm{C}$ and $60 \pm 4 \%$ of RH, for 16 days. * Significant at $5 \%$ of probability. Means followed by the same letter in the column do not differ statistically from each other by the Tukey test at $5 \%$ of significance. NV: non-vacuum; WV: with vacuum.

higher chlorophyll contents in the vacuum nylon/ polyethylene packing.
Furthermore, in the refrigerated condition (Table 2), it was observed that chilled fruits showed 
Table 2. Total chlorophyll and total extractable polyphenols of fresh murici fruits stored under different packing and atmosphere conditions and refrigerated $\left(12 \pm 2{ }^{\circ} \mathrm{C}\right.$ and $60 \pm 4 \%$ of RH) for 16 days.

\begin{tabular}{llll}
\hline \multirow{2}{*}{ Atmosphere } & \multicolumn{4}{c}{ Packing } \\
\cline { 2 - 4 } & \multicolumn{4}{c}{ PP } & LDPE & NY/PE \\
\hline \multirow{4}{*}{ Non-vacuum chlorophyll $\left(\mathrm{mg} \mathrm{g}^{-1}\right)$} \\
Vacuum & $283.02 \mathrm{aB}^{*}$ & $237.01 \mathrm{bA}$ & $215.02 \mathrm{bB}$ \\
\hline \multicolumn{4}{c}{ Total extractable polyphenols $\left(\mathrm{mg}\right.$ of gallic acid $\left.100 \mathrm{~g}^{-1}\right)$} \\
Non-vacuum & $319.47 \mathrm{bA}$ & $232.43 \mathrm{bA}$ & $359.62 \mathrm{aA}$ \\
Vacuum & $490.62 \mathrm{bA}^{*}$ & $590.17 \mathrm{aA}$ & $488.91 \mathrm{bB}$ \\
* Means followed by the same letter, lowercase in the row and uppercase in the \\
column, do not differ statistically from each other by the Tukey test at 5\% of \\
significance. PP: polypropylene; LDPE: low-density polyethylene; NY/PE: \\
nylon/polyethylene.
\end{tabular}

higher chlorophyll levels, since refrigeration reduces vegetal metabolic activities. This was also observed by Cerqueira (2012), when evaluating the storage of sweet peppers at different packages (pots, trays and bags) and temperatures $\left(8,15,20\right.$ and $25{ }^{\circ} \mathrm{C}$ ), for 12 days. These authors verified that the total chlorophyll contents were considerably greater at lower than higher temperatures. According to Heaton \& Marangoni (1996), this is because lower temperatures decrease the metabolism of agricultural products, hence increasing degradative processes and senescence.

Fruits packed with polypropylene and lowdensity polyethylene had a linear reduction in the chlorophyll contents from the beginning to the end of storage (Figure 4). The nylon/polyethylene and polypropylene packing showed better behaviors than the others, as contents had a slight increase until the 6th day, decreasing mildly until the 16th day, besides showing values close to the initial ones and higher than those of fruits packed with low-density polyethylene.

As for vacuum use, the total chlorophyll levels behaved similarly until the last day of analysis (Figure 5). Separately, the passive modified atmosphere (no vacuum) showed a constant decrease in the chlorophyll values until the end of storage. The use of vacuum also provided a decrease, but as of the 4th day of storage, when the means were higher, differing statistically from those under passive atmosphere. Regarding the same parameter, the use of vacuum had better results and was more stable than the passive atmosphere.

As for the contents of total extractable polyphenols, significant differences were observed for the packing and atmosphere factors. The highest content was found in fruits packed in low-density

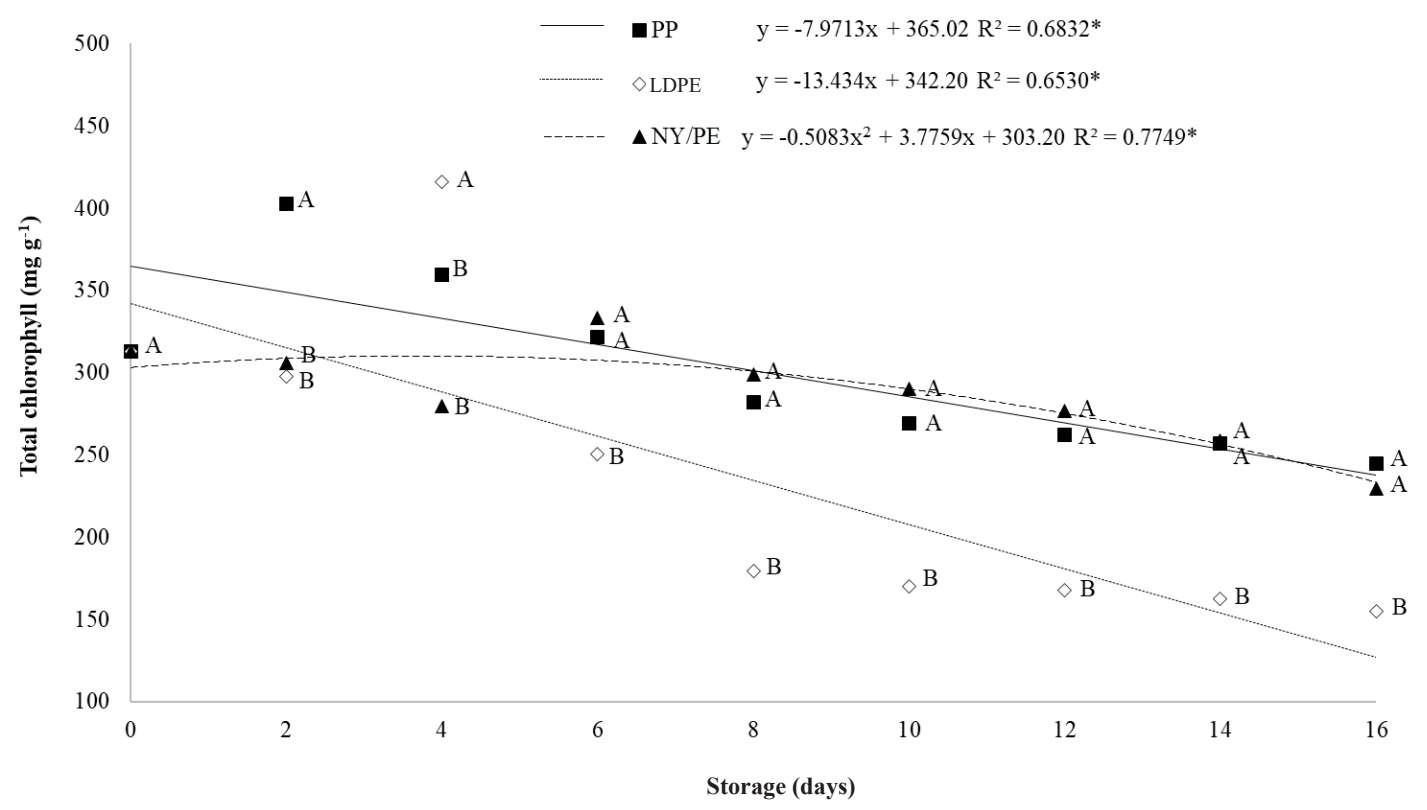

Figure 4. Total chlorophyll of fresh murici fruits packed in different materials and stored at $12 \pm 2{ }^{\circ} \mathrm{C}$ and $60 \pm 4 \%$ of $\mathrm{RH}$, for 16 days. * Significant at $5 \%$ of probability. Means followed by the same letter in the column do not differ statistically from each other by the Tukey test at $5 \%$ of significance. PP: polypropylene; LDPE: low-density polyethylene; NY/PE: nylon/ polyethylene. 


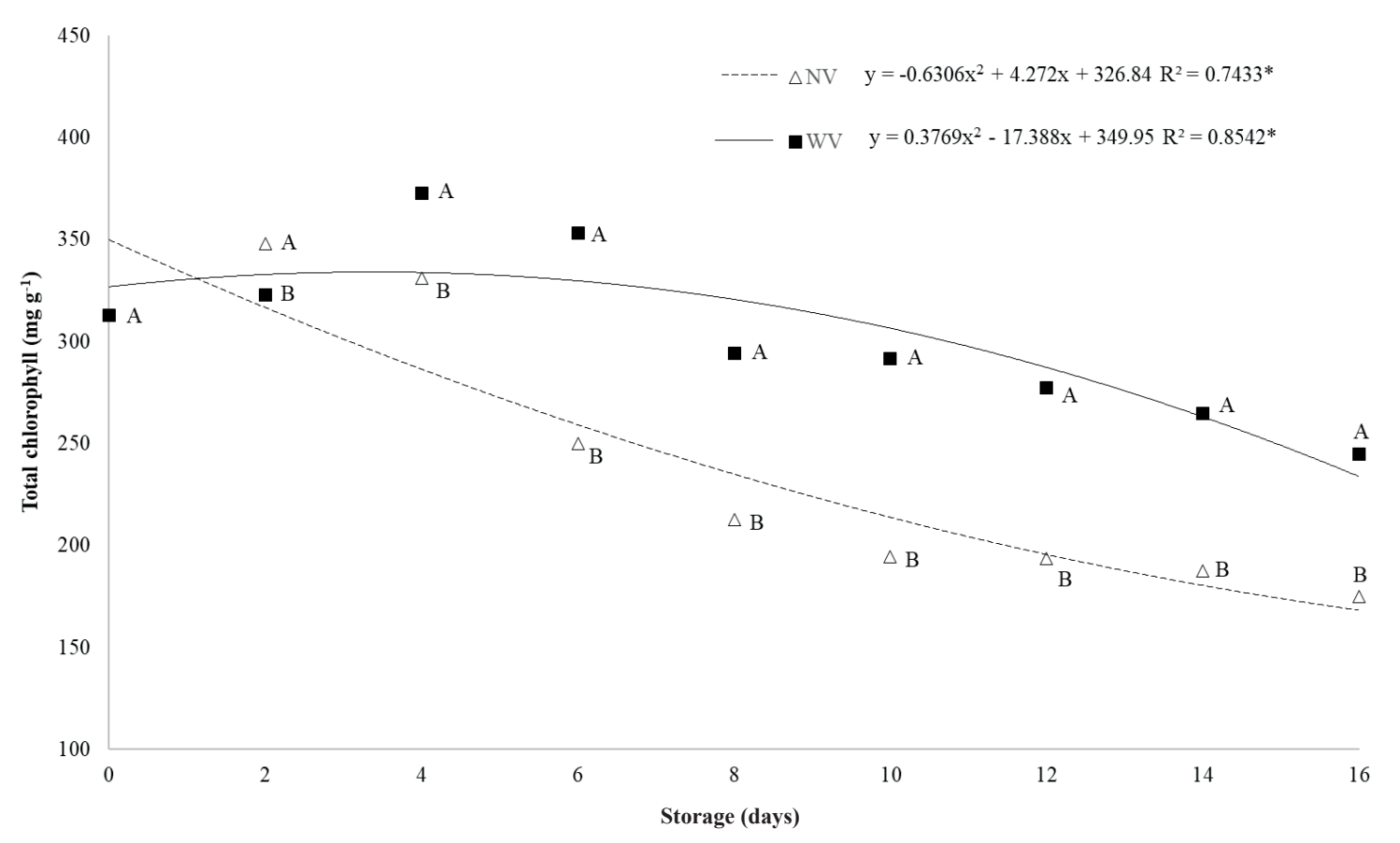

Figure 5. Total chlorophyll of fresh murici fruits packed in different modified atmospheres and stored at $12 \pm 2{ }^{\circ} \mathrm{C}$ and $60 \pm 4 \%$ of RH, for 16 days. * Significant at $5 \%$ of probability. Means followed by the same letter in the column do not differ statistically from each other by the Tukey test at $5 \%$ of significance. NV: non-vacuum; WV: with vacuum.

polyethylene film without vacuum, and the lowest one in polypropylene packing under vacuum condition. Lower levels of total extractable polyphenols were observed in polypropylene and nylon/polyethylene packing materials (Table 2), suggesting that fruits stored in these packing materials had pigments associated with darkening.

By comparing fruits packed in polypropylene and nylon/polyethylene, the levels of polyphenols were lower, since lower temperatures are efficient to maintain the quality of vegetables during storage (Hong et al. 2013), besides reducing the metabolism, water loss and fruit breathing, among others (Menolli et al. 2008).

The three packing materials used (low-density polyethylene, polypropylene and nylon/polyethylene) showed a linear behavior throughout the analysis period, and their determination coefficients were 76.29, 97.65 and $85.08 \%$, respectively (Figure 6).

Low-density polyethylene has an excellent corrosion resistance, outstanding insulation properties, absence of smell and taste, and low permeation of water vapor and gases, what is extremely important from industrial and technological points of view (Crippa 2006). Thus, the polyphenol contents increased more in fruits packed with low-density polyethylene during storage, as it is more permeable than the other materials, mainly than nylon/ polyethylene, which is a multilayered packing, what gives it a better barrier (Fabris et al. 2006). Overall, the polypropylene and nylon/polyethylene packing showed a similar behavior and had lower values during the storage of murici fruits.

Both the atmospheres with and without vacuum had an increase in the polyphenol contents over the course of the days. The vacuum treatment provided a lower overall average at the end of the experiment, standing out in terms of this parameter, as its averages were the lowest ones, constant, and statistically different from the vacuum treatment, after 8 days of storage (Figure 7).

The antioxidant activity increased until the end of storage in all treatments. This can be seen because the concentration of extract to react with $50 \%$ of the radical in the DPPH solution decreased. Vieira et al. (2011) reported that the extract has a high antioxidant activity at a low $\mathrm{EC}_{50}$ value. The three packing materials behaved similarly during storage, wherein their antioxidant power increased as the $\mathrm{EC}_{50} \mathrm{~g} \mathrm{~g}^{-1}$ of DPPH values decreased (Figure 8). The treatment showing a trend of greater activity during the 16 days of storage was nylon/polyethylene packing. 


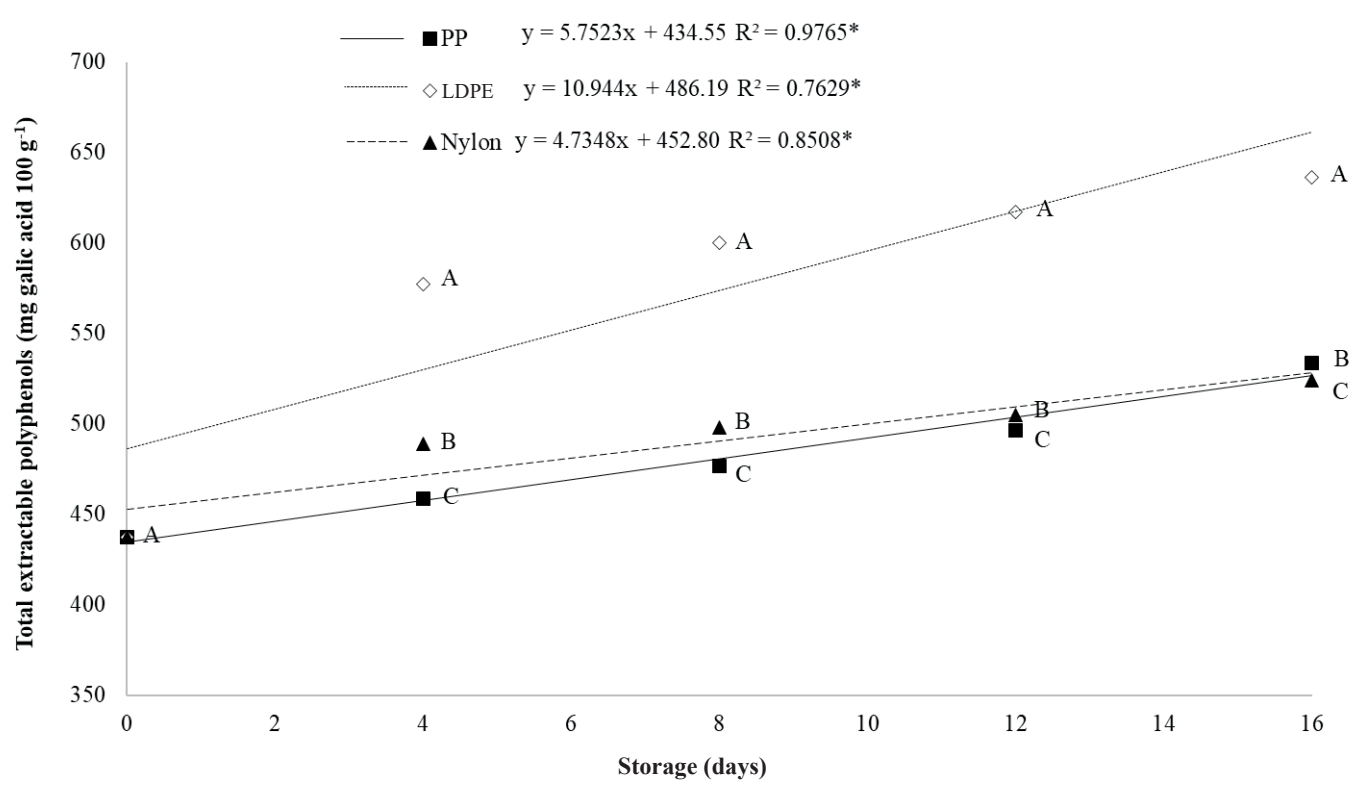

Figure 6. Total extractable polyphenols of fresh murici fruits packed in different materials and stored at $12 \pm 2{ }^{\circ} \mathrm{C}$ and $60 \pm 4 \%$ of RH, for 16 days. * Significant at $5 \%$ of probability. Means followed by the same letter in the column do not differ statistically from each other by the Tukey test at $5 \%$ of significance. PP: polypropylene; LDPE: low-density polyethylene; NY/PE: nylon/polyethylene.

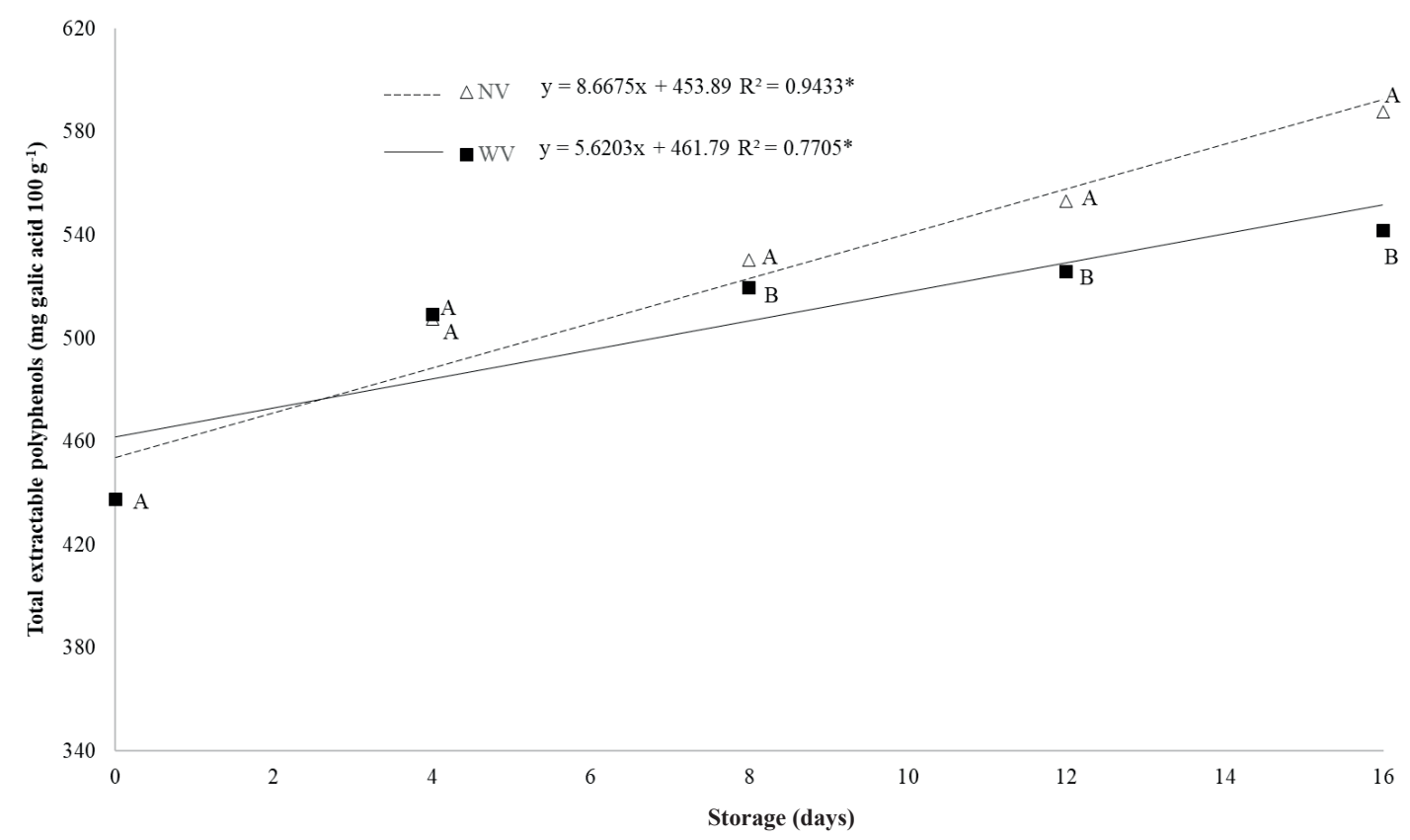

Figure 7. Total extractable polyphenols of fresh murici fruits packed in different modified atmospheres and stored at $12 \pm 2{ }^{\circ} \mathrm{C}$ and $60 \pm 4 \%$ of RH, for 16 days. * Significant at $5 \%$ of probability. Means followed by the same letter in the column do not differ statistically from each other by the Tukey test at $5 \%$ of significance. NV: non-vacuum; WV: with vacuum.

The antioxidant capacity is probably due to phenolic compounds, which are important antioxidants (Couto \& Canniatti-Brazaca 2010). In general, since phenolic compounds increase over time, an increase in the antioxidant activity is also expected (Neves et al. 2015). This can be seen in this study, given the increase in polyphenols (Figure 6). Likewise, Rosa et al. (2016) explained 


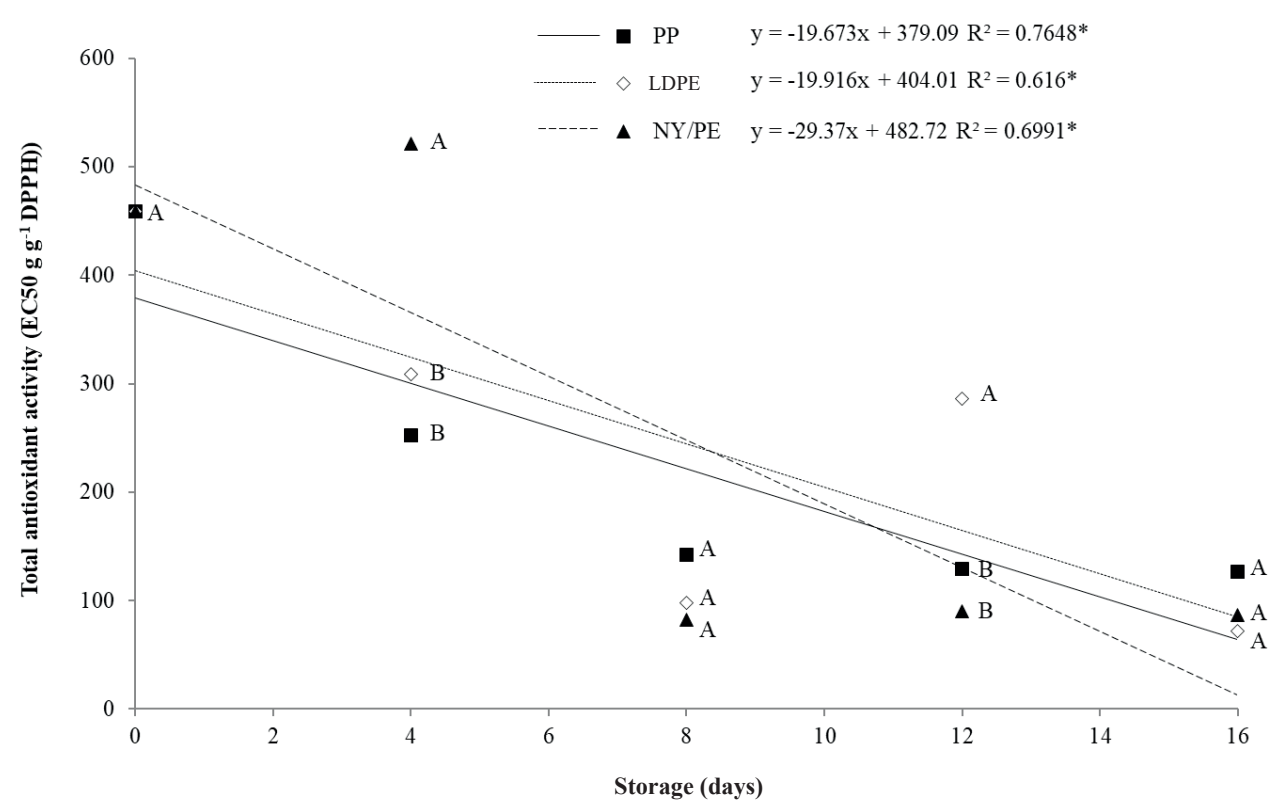

Figure 8. Total antioxidant activity of fresh murici fruits stored in different packing materials at $12 \pm 2{ }^{\circ} \mathrm{C}$ and $60 \pm 4 \%$ of RH, for 16 days. * Significant at $5 \%$ of probability. Means followed by the same letter in the column do not differ statistically from each other by the Tukey test at $5 \%$ of significance. PP: polypropylene; LDPE: low-density polyethylene; NY/PE: nylon/polyethylene.

that murici fruits have a high level of antioxidant capacity, probably due to large amounts of phenolic compounds therein.

\section{CONCLUSION}

In terms of minimum acceptable postharvest characteristics for murici fruits, polypropylene and nylon/polyethylene packing materials combined with vacuum promote better results for the analyzed parameters.

\section{ACKNOWLEDGMENTS}

This study was partly financed by the Coordenação de Aperfeiçoamento de Pessoal de Nível Superior - Brasil (Capes) - Finance Code 001 (Agreement between UEG and Capes, $n^{\circ} .817164 / 2015$ Capes/Proap).

\section{REFERENCES}

ALEGRETTI, A. L.; WAGNER JUNIOR, A.; BORTOLINI, A.; HOSSEL, C.; ZANELA, J.; CITADIN, I. Armazenamento de sementes de cerejas-do-mato (Eugenia involucrata) DC. submetidas ao recobrimento com biofilmes e embalagem a vácuo. Revista Ceres, v. 62, n. 1, p. 124-127, 2015.
ARRUDA, M. C.; JACOMINO, A. P.; TREVISAN, M. J.; JERONIMO, E. M.; MORETTI, C. L. Atmosfera modificada em laranja 'Pera' minimamente processada. Bragantia, v. 70, n. 3, p. 664-671, 2011.

BELISÁRIO, C. M.; CONEGLIAN, R. C. C. Qualidade de frutos de murici (Byrsonima crassifolia, Malpighiaceae) armazenados sob refrigeração. Global Science and Technology, v. 6, n. 2, p. 95-101, 2013.

BRAND-WILIAMS, W.; CUVELIER, M. E.; BERSET, C. Use of a free radical method to evaluate antioxidant activity. Lwt-Food Science and Technology, v. 28, n. 1, p. 25-30, 1995.

BRUNINI, M. A.; CARDOSO, S. S. Qualidade de pitaias de polpa branca armazenadas em diferentes temperaturas. Revista Caatinga, v. 24, n. 3, p. 78-84, 2011.

CARAMORI, S. S.; LIMA, C. S.; FERNANDES, K. F. Biochemical characterization of selected plant species from Brazilian Savannas. Brazilian Archives of Biology and Technology, v. 47, n. 2, p. 253-259, 2004.

CERQUEIRA, A. P. Conservação pós-colheita de pimentas-de-cheiro (Capsicum Chinense) armazenadas sob atmosfera modificada e refrigeração. Dissertação (Mestrado em Produção Vegetal) - Universidade Federal do Tocantins, Gurupi, 2012.

CERQUEIRA, T. S. Recobrimentos comestiveis em goiabas cv. 'Kumagai'. Dissertação (Mestrado em Ciências) - Escola Superior de Agricultura "Luiz de 
Queiróz", Universidade de São Paulo, Piracicaba, 2007.

COUTO, M. A. L.; CANNIATTI-BRAZACA, M. A. L. Quantificação de vitamina $C$ e capacidade antioxidante de variedades cítricas. Ciência e Tecnologia de Alimentos, v. 30, n. 1, p. 15-19, 2010.

CRIPPA, A. Estudo do desempenho de filmes multicamadas em embalagens termoformadas. Dissertação (Mestrado em Engenharia de Materiais) - Universidade Federal do Paraná, Curitiba, 2006.

CRIPPA, A.; SYDENSTRICKER, T. H. D.; AMICO, S. C. Desempenho de filmes multicamadas em embalagens termoformadas. Polímeros, v. 17, n. 3, p. 188-193, 2007.

DIAS, T. C.; MOTA, W. F.; OTONI, B. S.; MIZOBUTSI, G. P.; SANTOS, M. G. P. Conservação pós-colheita de mamão Formosa com filme de PVC e refrigeração. Revista Brasileira de Fruticultura, v. 33, n. 2, p. 666-670, 2011.

FABRIS, S.; FREIRE, M. T. A.; REYES, F. G. R. Embalagens plásticas: tipos de materiais, contaminação de alimentos e aspectos de legislação. Revista Brasileira de Toxicologia, v. 19, n. 2, p. 59-70, 2006.

FERREIRA, D. F. Sisvar: um sistema computacional de análise estatística. Ciência e Agrotecnologia, v. 35, n. 6, p. 1039-1042, 2011.

HEATON, J. W.; MARANGONI, A. G. Chlorophyll degradation in processed foods and senescent plant tissues. Trends in Food Science and Techonology, v. 7, n. 1, p. 8-15, 1996.

HONG, K.; XU, H.; WANG, L.; ZHANG, L.; HU, H.; JIA, Z.; GU, H.; HE, Q.; GONG, D. Quality changes and internal browning developments of summer pineapple fruit during storage at different temperatures. Scientia Horticulturae, v. 151, n. 28, p. 68-74, 2013.

LICHTENTHALER, H. K. Chlorophylls and carotenoids: pigment of photosynthetic biomembranes. Methods in Enzymology, v. 148, n. 1, p. 350-382, 1987.

LIMA, J. P.; RODRIGUES, L. F.; MONTEIRO, A. G. D. P.; VILAS BOAS, E. V. B. Climacteric pattern of mangaba fruit (Hancornia speciosa Gomes) and its responses to temperature. Scientia Horticulturae, v. 197, n. 14, p. 399403, 2015.

LOURENÇO, I. P.; FIGUEIREDO, R. W.; ALVES, R. E.; ARAGÃO, F. A. S.; MOURA, C. F. H. Caracterização de frutos de genótipos de muricizeiros cultivados no litoral cearense. Revista Ciência Agronômica, v. 44, n. 3, p. 499504, 2013.

MACHADO, N. P.; COUTINHO, E. F.; CAETANO, E. R. Embalagens plásticas e refrigeração na conservação póscolheita de jabuticabas. Revista Brasileira de Fruticultura, v. 29, n. 1, p. 166-168, 2007.
MACKINNEY, G. Absorption of light by chlorophyll solutions. Journal of Biological Chemistry, v. 140, n. 2, p. 315-322, 1941.

MENOLLI, L. N.; FINGER, F. L.; PUIATTI, M.; BARBOSA, J. M.; BARROS, R. S. Atuação das enzimas oxidativas no escurecimento causado pela injúria por frio em raízes de batata - baroa. Acta Scientarium: Agronomy, v. 30, n. 1, p. 57-63, 2008.

MORZELlE, M. C.; BACHIEGA, P.; SOUZA, E. C.; VILAS BOAS, E. V. B.; LAMOUNIER, M. L. Caracterização química e física de frutos de curriola, gabiroba e murici provenientes do Cerrado brasileiro. Revista Brasileira de Fruticultura, v. 37, n. 1, p. 96-103, 2015.

MOTA, V. A. Armazenamento de murici (Brysonima crassifolia (L.) Kunth em diferentes temperaturas com aplicação de biofilme. Dissertação (Mestrado em Produção Vegetal) - Universidade Estadual de Maringá, Maringá, 2014.

NASSUR, R. D. C. M. R.; LIMA, R. A. Z.; LIMA, L. C. O.; CHALFUN, N. N. J. Doses de radiação gama na conservação da qualidade de morangos. Comunicata Scientiae, v. 7, n. 1, p. 38-48, 2016.

NEVES, L. C.; TOSIN, J. M.; BENEDETTE, R. M.; CISNEROS-ZEVALOS, L. Post-harvest nutraceutical behaviour during ripening and senescence of 8 highly perishable fruit species from the northern Brazilian Amazon region. Food Chemistry, v. 174, n. 1, p. 188196, 2015.

OBANDA, M.; OWUOR, P. O. Flavanol composition and caffeine content of green leaf as quality potential indicators of Kenyan black teas. Journal of the Science of Food and Agriculture, v. 74, n. 2, p. 209-215, 1997.

PRENTICE, C.; SAINZ, R. L. Cinética de deterioração apresentada por filés de carpa-capim (Ctenopharyngodon idella) embalados a vácuo sob diferentes condições de refrigeração. Ciência e Tecnologia de Alimentos, v. 25, n. 1, p. 27-131, 2005.

ROSA, F. R.; ARRUDA, A. F.; ARRUDA, S. F.; ARRUDA, S. F. Phytochemical compounds and antioxidant capacity of tucum-do-cerrado (Bactris setosa Mart), Brazil's native fruit. Nutrients, v. 8, n. 3, p. 110-126, 2016.

RUFINO, M. S. M.; ALVES, R. E.; BRITO, E. S.; PÉREZJIMÉNEZ, J.; SAURA-CALIXTO, F.; MANCINI- FILHO, J. Bioactive compounds and antioxidant capacities of 18 non traditional tropical fruits from Brazil. Food Chemistry, v. 121, n. 4, p. 996-1002, 2010.

SAMPAIO, C. R. P. Caracterização físico-química, capacidade antioxidante e compostos bioativos de frutos de murici vermelho (Byrsonima ligustrifolia A. Juss.) em cinco estágios de maturação. Tese (Doutorado em 
Tecnologia de Alimentos) - Universidade Federal do Paraná, Curitiba, 2015.

SANTANA, L. R. R.; BENEDETTI, B. C.; SIGRIST, J. M. M.; SATO, H. H.; ANJOS, V. D. de A. Effect of controlled atmosphere on postharvest quality of 'Douradão' peaches. Ciência e Tecnologia de Alimentos, v. 31, n. 1, p. 231-237, 2011.

SILVA, M. C.; SOUZA, V. B.; THOMAZINI, M.; SILVA, E. R.; SMANIOTTO, T.; CARVALHO, R. A.; GENOVESE, M. I.; FAVARO-TRINDADE, C. S. Use of the jabuticaba (Myrciaria cauliflora) depulping residue to produce a natural pigment powder with functional properties. LWT-Food Science and Technology, v. 55, n. 1, p. 203-209, 2014.

SOUZA, P. M.; ELIAS, S. T.; SIMEONI, L. A.; PAULA, J. E.; GOMES, S. M.; GUERRA, E. N. S.; FONSECA,
Y. M.; SILVA, E. C.; SILVEIRA, D.; MAGALHÃES, P. O. Plants from Brazilian Cerrado with potent tyrosinase inhibitory activity. Plos One, v. 7, n. 11, p. 1-7, 2012.

TOMAZ, H. V. D. Q.; AROUCHA, E. M. M.; NUNES, G. H. D. S.; BEZERRA NETO, F.; QUEIROZ, R. F. Qualidade pós-colheita de diferentes híbridos de melãoamarelo armazenados sob refrigeração. Revista Brasileira de Fruticultura, v. 31, n. 4, p. 987-994, 2009.

VIEIRA, L. M.; SOUZA, M. S. B.; MANCINI-FILHO, J.; LIMA, A. Fenólicos totais e capacidade antioxidante in vitro de polpas de frutos tropicais. Revista Brasileira de Fruticultura, v. 33, n. 3, p. 888-897, 2011.

VIEITES, R. L.; RUSSO, V. C.; DAIUTO, E. R. Qualidade do abacate 'Hass' frigoarmazenado submetido a atmosferas modificadas ativas. Revista Brasileira de Fruticultura, v. 36, n. 2, p. 329-338, 2014. 